University of Nebraska - Lincoln

DigitalCommons@University of Nebraska - Lincoln

January 2004

Comparisons of Angus, Charolais, Galloway, Hereford, Longhorn, Nellore, Piedmontese, Salers, and Shorthorn breeds for weight, weight adjusted for condition score, height, and condition score of cows

Jesus Arango

University of Nebraska-Lincoln, jarango2@unl.edu

L. V. Cundiff

USDA, ARS, Roman L. Hruska U.S. Meat Animal Research Center

L. Dale Van Vleck

University of Nebraska-Lincoln, dvan-vleck1@unl.edu

Follow this and additional works at: https://digitalcommons.unl.edu/animalscifacpub

Part of the Animal Sciences Commons

Arango, Jesus; Cundiff, L. V.; and Van Vleck, L. Dale, "Comparisons of Angus, Charolais, Galloway, Hereford, Longhorn, Nellore, Piedmontese, Salers, and Shorthorn breeds for weight, weight adjusted for condition score, height, and condition score of cows" (2004). Faculty Papers and Publications in Animal Science. 201.

https://digitalcommons.unl.edu/animalscifacpub/201

This Article is brought to you for free and open access by the Animal Science Department at DigitalCommons@University of Nebraska - Lincoln. It has been accepted for inclusion in Faculty Papers and Publications in Animal Science by an authorized administrator of DigitalCommons@University of Nebraska - Lincoln. 


\title{
Comparisons of Angus, Charolais, Galloway, Hereford, Longhorn, Nellore, Piedmontese, Salers, and Shorthorn breeds for weight, weight adjusted for condition score, height, and condition score of cows ${ }^{1}$
}

\author{
J. A. Arango ${ }^{* 2}$, L. V. Cundiff $\dagger$, and L. D. Van Vleck $\neq^{3}$ \\ *Department of Animal Science, University of Nebraska, Lincoln 68583-0908 and USDA, ARS, \\ Roman L. Hruska U.S. Meat Animal Research Center, †Clay Center, NE 68933 and $\ddagger$ Lincoln, NE 68583-0909
}

\begin{abstract}
Breed differences for weight (CW), height $(\mathrm{CH})$, and condition score $(\mathrm{CS})$ were estimated from records $(\mathrm{n}=12,188)$ of 2 - to 6 -yr-old cows $(\mathrm{n}=$ 744) from Cycle IV of the U.S. Meat Animal Research Center's Germplasm Evaluation (GPE) Program. Cows were produced from mating Angus and Hereford dams to Angus, Hereford, Charolais, Shorthorn, Galloway, Longhorn, Nellore, Piedmontese, and Salers sires. Samples of Angus and Hereford sires were 1) reference sires born from 1962 through 1970 and 2) 1980s sires born in 1980 through 1987. The mixed model included cow age, season of measurement and their interactions, year of birth, pregnancy-lactation code (PL), and breedgroup as fixed effects for CW and CS. Analyses of weight adjusted for condition score included CS as a linear covariate. The model for CH excluded PL. Random effects were additive genetic and permanent environmen-
\end{abstract}

tal effects associated with the cow. Differences among breed groups were significant $(P<0.05)$ for all traits and were maintained through maturity with few interchanges in ranking. The order of $F_{1}$ cows for weight was as follows: Charolais (506 to $635 \mathrm{~kg}$ for different ages), Shorthorn and Salers, reciprocal Hereford-Angus (HA) with 1980s sires, Nellore, HA with reference sires, Galloway, Piedmontese, and Longhorn (412 to $525 \mathrm{~kg}$ for different ages). Order for height was as follows: Nellore (136 to $140 \mathrm{~cm}$ ), Charolais, Shorthorn, Salers, HA with 1980s sires, Piedmontese, Longhorn, Galloway and HA with reference sires (126 to $128 \mathrm{~cm}$ ). Hereford and Angus cows with reference sires were generally lighter than those with 1980s sires. In general, breed differences for height followed those for weight except that $F_{1}$ Nellore cows were tallest, which may in part be due to Bos taurus-Bos indicus heterosis for size.

Key Words: Beef Cattle, Breeds, Growth, Maturity

(c2004 American Society of Animal Science. All rights reserved.

J. Anim. Sci. 2004. 82:74-84

\section{Introduction}

Mature size, as a component of efficiency, is more important in beef cattle than in other meat livestock because of low rate of reproduction and high maternal cost of cows (Dickerson, 1978). The Germplasm Evaluation (GPE) Program (Cundiff et al., 1986) at the U.S. Meat Animal Research Center (USMARC) was designed to evaluate breeds of sires differing in genetic potential for diverse economic traits, such as growth

\footnotetext{
${ }^{1}$ Published as Paper No. 14007, Journal Ser., Nebraska Agric. Res. Div., Univ. of Nebraska, Lincoln 68583-0908.

${ }^{2}$ Current address: Facultad de Ciencias Veterinarias, Universidad Central de Venezuela, Apartado 4563, Maracay 2101, Aragua, Venezuela.

${ }^{3}$ Correspondence: A218 Animal Sciences (phone: 402-472-6010; fax: 402-472-6362; e-mail: lvanvleck@unlnotes.unl.edu).

Received February 25, 2003.

Accepted August 27, 2003.
}

and mature size, milk production, lean-to-fat ratio, and carcass characteristics.

Analyses of mature weight and height and condition score for cows in Cycles I to III were presented in previous reports (Arango et al., 2002b,c,d). An earlier report from MARC presented ordinary least squares means and breed differences for weight and height for heifers from Cycle IV of the GPE (Thallman et al., 1999). The goal of this study was to estimate breed differences for weight, weight adjusted for condition score, height and body condition score of cows produced by Hereford and Angus dams and Hereford, Angus, Charolais, Shorthorn, Galloway, Nellore, Piedmontese and Salers sires in Cycle IV of the GPE Program.

\section{Materials and Methods}

Data were collected from five calving seasons (1986 through 1990). Angus and Hereford cows were inseminated with semen from Hereford and Angus reference bulls; 1980s Angus bulls (born in 1980 through 1987); 
Table 1. Number of sires and cows by breed of sire for Cycle IV

\begin{tabular}{lcc}
\hline \hline Breed of sire & Sires & Cows \\
\hline Reference Hereford $^{\mathrm{a}}$ & 10 & $74^{\mathrm{c}}$ \\
Reference Angus $^{\mathrm{a}}$ & 20 & $77^{\mathrm{d}}$ \\
${\text { 1980 } \text { sereford }^{\mathrm{b}}}_{\text {1980 Angus }}^{\mathrm{b}}$ & 27 & $52^{\mathrm{e}}$ \\
Charolais $_{\text {Galloway }}$ & 19 & $37^{\mathrm{f}}$ \\
Longhorn & 22 & 35 \\
Nellore & 27 & 70 \\
Piedmontese & 24 & 81 \\
Salers & 22 & 81 \\
Shorthorn & 18 & 83 \\
Total & 25 & 86 \\
\hline
\end{tabular}

${ }^{\text {a}}$ Hereford reference sires were born from 1962 through 1969 (mean $=1,965.7)$. Angus reference sires were born from 1968 through 1970 $($ mean $=1,968.8)$.

${ }^{\mathrm{b}} 1980$ s Hereford sires were born from 1980 through 1986 (mean $=$ 1,983.3). 1980s Angus sires were born from 1981 through 1987 (mean $=1,984.0$ ).

'32 purebred Hereford, 42 Hereford-Angus.

d35 purebred Angus, 42 Angus-Hereford.

e 22 purebred Hereford, 30 Hereford-Angus.

${ }^{\mathrm{f}} 13$ purebred Angus, 24 Angus-Hereford.

1980s Hereford bulls (horned and polled, born in 1982 through 1984); and Longhorn, Piedmontese, Charolais, Salers, Galloway, Nellore, and Shorthorn bulls. The numbers of sires and cows from each breed of sire are presented in Table 1. Original reference sires were repeated over years and cycles to increase ties with previous cycles and to facilitate the pooling of results over all four cycles. The 1980s bulls represented a more current sample of Hereford and Angus sires to account for genetic trend that had occurred within the Hereford and Angus breeds. Therefore, "reference" and "1980s" Angus and Hereford bulls were treated as different breed groups in the analysis. Charolais sires used in Cycle IV (born in 1981 through 1987) also represented a new sample of sires, different from the Charolais bulls used in Cycle I (Arango et al., 2002b). Details of the sampling of sires and the experimental design have been presented by Cundiff et al. (1998) and Thallman et al. (1999).

General management was described by Cundiff et al. (1998). Cows were maintained on improved pasture (late April to late November) of cool-season smooth bromegrass (Bromus inerous) or warm-season mixtures of predominantly big bluestem (Andropogon gerardii), switch grass (Panicum virgatum), Indian grass (Sorghastrum nutans), with some little bluestem (Schizachyrium scoparium), side oats gramma (Bouteloua curtipendula), and sand lovegrass (Eragrostis trichoides). During the winter months, when grass was not available (usually from late November to late April), females were fed supplemental silage or hay. As 2-yr-olds, females were fed a diet containing $70 \%$ alfalfa haylage and 30\% corn silage (approximately 35\% DM, 32 to 43 $\mathrm{kg} / \mathrm{d})$. The same diet was fed to the females at $3 \mathrm{yr}$ of age $(36$ to $38 \mathrm{~kg} / \mathrm{d})$. At $4 \mathrm{yr}$ of age and older, females were fed alfalfa hay $4 \mathrm{~d} / \mathrm{wk}$ and grass hay three alternate days of the week (11 to $14 \mathrm{~kg} / \mathrm{d}$ ). Cows born in the same year were treated as a contemporary group for nearly all analyses. In Cycle IV, that was true for heifers and young cows (yearling to 3-yr-old females); however, when cows reached $4 \mathrm{yr}$ of age or older, they were run in two groups (i.e., those born 1986 to 1988 in one, and those born in 1989 and 1990 in another). Yearling heifers were weighed at the beginning and end of the mating season, and when palpated for pregnancy. Thereafter, cows were weighed, measured for hip height, and scored for body condition four times each year. One measurement was taken each season: 1 ) midMay (spring) at the start of the breeding season; 2) early August (summer) at the end of the breeding season; 3) end of October (fall) at palpation for pregnancy following weaning; and 4) early February (winter) before calving. Body condition score was based on a subjective, 9point classification scale, from extremely thin $(1=$ very emaciated) to extremely fat $(9=$ very obese). Each record of a cow was assigned to one of four physiological codes composed of a combination of lactation ( $1=$ not lactating, 2 = lactating) code and pregnancy ( $1=$ not pregnant, $2=$ pregnant) code. Data for the present study included records of cows from 2 through $6 \mathrm{yr}$ of age (the oldest age allowed for any cow).

Statistical analyses used single-trait animal models with a derivative-free REML algorithm (Boldman et al., 1995). Fixed effects were sire line, dam line and their interactions, age and season of measurement and their interactions, year of birth, and pregnancy-lactation code in models for cow weight and body condition score. For cow height, pregnancy-lactation code was excluded. Analyses of weight adjusted for condition score included condition score as a covariate. Adjustment was to the average condition score for the analysis. Separate analyses by age (years) of cow included age in days within season of measurement as extra covariates. Random effects were additive genetic and permanent environmental effects of the cow. Details about models and estimation of variance components were presented by Arango et al. (2002a).

Estimates of (co)variances at convergence were used with mixed model equations to estimate linear contrasts for breed of sire comparisons. More comparisons were made than there were independent degrees of freedom. Therefore, the error rate may be somewhat different from the nominal indicated by the level of probability. However, the experimental objective was to examine breed-of-sire effects on major economic traits by comparing all breeds of sires with Hereford-Angus (HA) crosses and with each other (Cundiff et al., 1986). Tests of significance will be guides of whether the observed values could have occurred by chance. The standard breed group for comparison of breeds of sire (within and across cycles) was the HA reciprocal cross. The following nine contrasts were tested for each trait and age at measurement (years): 1) the difference between the average for cows with each breed of sire and the 
Table 2. Numbers of cows $(\mathrm{N})$, measurements (n), and unadjusted means ( \pm SD) by age for weight $(\mathrm{kg})$, hip height $(\mathrm{cm})$, and body condition score (points)

\begin{tabular}{|c|c|c|c|c|c|c|c|}
\hline \multirow[b]{2}{*}{ Age, yr } & \multirow[b]{2}{*}{$\mathrm{N}$} & \multicolumn{2}{|c|}{ Weight } & \multicolumn{2}{|c|}{ Height } & \multicolumn{2}{|c|}{ Condition score } \\
\hline & & $\mathrm{n}$ & Mean & $\mathrm{n}$ & Mean & $\mathrm{n}$ & Mean \\
\hline 2 & 742 & 2,946 & $460 \pm 54$ & 2,946 & $130 \pm 4.5$ & 2,944 & $6.1 \pm 0.73$ \\
\hline 3 & 742 & 2,831 & $520 \pm 66$ & 2,831 & $133 \pm 5.8$ & 2,830 & $6.1 \pm 0.082$ \\
\hline 4 & 718 & 2,701 & $546 \pm 63$ & 2,701 & $133 \pm 5.8$ & 2,700 & $6.2 \pm 0.88$ \\
\hline 5 & 582 & 2,193 & $556 \pm 63$ & 2,193 & $132 \pm 5.8$ & 2,187 & $6.3 \pm 0.87$ \\
\hline 6 & 438 & 1,517 & $554 \pm 62$ & 1,517 & $132 \pm 5.6$ & 1,516 & $6.4 \pm 0.79$ \\
\hline
\end{tabular}

average of HA cows (with 1980s sires), 2) the difference between Angus and Hereford purebred cows and their reciprocal crosses produced by "reference sires," 3) same as Contrast 2 but produced by "1980s" sires, 4) the difference between Hereford and Angus 1980s and reference sires, 5) the difference between Angus 1980s and Angus reference sires, 6) same as Contrast 5 but for Hereford sires, 7) the difference between 1980s Hereford and Angus sires, 8) the difference between reference Hereford sires and reference Angus sires, and 9) the difference between cows with Angus dams and cows with Hereford dams. Contrasts 5 and 6 are estimates of genetic trend for the Hereford and Angus breeds. Differences among crossbred cows will be due to additive genetic effects present in the specific two-breed crosses and to heterosis for a particular cross (e.g., Frahm and Marshall, 1985). Heterosis was assumed to be of similar magnitude for most crosses because the design effectively confounded breed of sire and specific heterosis effects except for the embedded Hereford-Angus diallel. Cows with Nellore sires would be expected to express extra heterosis resulting from the Bos indicus $\times$ Bos taurus cross (Koger, 1980).

\section{Results and Discussion}

\section{Cow Weights}

Numbers and means by age of cow are listed in Table 2. Cows gained weight until $5 \mathrm{yr}$ of age. The largest yearly gain was from 2 to $3 \mathrm{yr}$ of age, accounting for $64 \%$ of the total gain from 2 to $6 \mathrm{yr}$ of age. By $4 \mathrm{yr}$ of age, cows had accumulated most (98.6\%) of their final weight. Unadjusted means for height did not change much across ages, except between 2 and $3 \mathrm{yr}$ of age, which indicates that stature reaches maturity earlier than weight. Cows had attained $98.5 \%$ of their final height by $2 \mathrm{yr}$ of age. Changes in means for condition score (maximum 0.3 point) were minor across ages.

Estimates of breed means for weight by age (years) are shown in Table 3. Ranking of crossbred cows (by breed of sire) was conserved across ages, in the following order: Charolais (heaviest), Shorthorn, Salers, Hereford, and Angus (1980s sires); Nellore, Hereford, and Angus (reference sires); Galloway, Piedmontese, and Longhorn (lightest). The only exception was that means for cows with Galloway sires (439 kg) were less than those with Piedmontese sires $(444 \mathrm{~kg}$ ) at $2 \mathrm{yr}$ of age.

Estimates of breed-group contrasts are presented in Table 4. Cows with Charolais sires were consistently heavier $(P<0.01)$ than HA cows at every age by differences that tended to increase with age, ranging from 32 to $76 \mathrm{~kg}$. Cows with Salers and Shorthorn sires also were heavier than HA cows, but the differences were not significant until 5 and $3 \mathrm{yr}$ of age for Salers and Shorthorn sires, respectively. The Nellore-sired cows did not differ significantly from HA cows. Cows with Longhorn, Galloway, and Piedmontese sires were always lighter than HA cows by differences that tended to increase until $4 \mathrm{yr}$ of age $(P<0.01)$ and then decreased. At 5 yr of age, the differences were highly significant for cows with Longhorn $(-44 \mathrm{~kg})$ and Piedmontese $(-32 \mathrm{~kg})$ sires. The difference was highly significant for cows with Galloway $(25 \mathrm{~kg})$ sires. At $6 \mathrm{yr}$ of age, the difference was significant only for cows with Longhorn sires. In general, breed group means for cow weight were greater for cows sired by breeds of large size and low milk production (Charolais) than for cows by breeds of sire of large size and moderate milk production (Salers and Shorthorn) and for cows by breeds of sire of moderate size and low milk production (Galloway, Longhorn, and Piedmontese). Cows with Bos indicus sires (Nellore) constituted a separate group and were intermediate for weight. They ranked between Bos taurus breeds of large size and Bos Taurus breeds of moderate size, and ranked, in general, close to HA cows.

The reciprocal HA cows, with reference sires, were heavier than the average of the purebred Hereford and Angus cows by differences that tended to decrease with age: $19 \mathrm{~kg}$ at $2 \mathrm{yr}(P<0.01)$ and $17 \mathrm{~kg}$ at 3 and $4 \mathrm{yr}(P$ $<0.05$ ). Earlier studies (e.g., Smith et al., 1976) have reported greater heterosis at younger ages. At $6 \mathrm{yr}$ of age, the difference was only $5 \mathrm{~kg}(P>0.05)$. Estimates of direct heterosis from 2 to $5 \mathrm{yr}$ of age (3 to $4 \%$ ) were intermediate between those in Cycle I (4 to 6\%) and Cycle II (2 to 5\%) (Arango et al., 2002b,c) for cow weight. Corresponding differences for cows with 1980s sires (-16 to $6 \mathrm{~kg}$ ) were not significant at any age. Cows with 1980s Hereford and Angus sires, averaged over straightbred and crossbred matings, were consistently heavier $(P<0.01)$ than cows with Hereford and Angus reference sires by differences that ranged from 29 to 
Table 3. Estimates of breed-group means for cow weight $(\mathrm{kg})$ by age of measurement ${ }^{\mathrm{a}}$

\begin{tabular}{lccccr}
\hline \hline & \multicolumn{4}{c}{ Age of cow, yr } \\
\cline { 2 - 5 } $\begin{array}{l}\text { Breed } \\
\text { group }\end{array}$ & 2 & 3 & 4 & 5 & 6 \\
\hline H reference & 419 & 479 & 506 & 515 & 523 \\
A reference & 442 & 503 & 525 & 534 & 544 \\
H 1980s & 476 & 545 & 576 & 579 & 604 \\
A 1980s & 466 & 523 & 541 & 548 & 542 \\
HA reference & 451 & 508 & 533 & 538 & 538 \\
AH reference & 448 & 508 & 533 & 541 & 540 \\
HA 1980s & 482 & 556 & 575 & 582 & 569 \\
AH 1980s & 471 & 535 & 560 & 534 & 544 \\
Ch-H & 510 & 599 & 623 & 635 & 635 \\
Ch-A & 506 & 585 & 616 & 633 & 623 \\
So-H & 489 & 561 & 586 & 597 & 595 \\
So-A & 494 & 567 & 590 & 598 & 599 \\
Ga-H & 435 & 503 & 523 & 529 & 536 \\
Ga-A & 442 & 508 & 531 & 537 & 546 \\
Lh-H & 417 & 474 & 500 & 518 & 525 \\
Lh-A & 412 & 471 & 492 & 510 & 512 \\
Ne-H & 464 & 542 & 565 & 565 & 558 \\
Ne-A & 466 & 534 & 555 & 553 & 553 \\
Pd-H & 440 & 493 & 515 & 523 & 533 \\
Pd-A & 448 & 497 & 517 & 527 & 537 \\
Sa-H & 481 & 545 & 567 & 563 & 604 \\
Sa-A & 495 & 563 & 584 & 600 & \\
\hline
\end{tabular}

${ }^{a}$ Means were obtained by adding the unadjusted mean for HA cows, the solution constrained to zero, to the solution for each breed-group.

${ }^{b}$ Reference sires born from 1962 through 1970; 1980s = sires born from 1980 through 1987; H = Hereford, $\mathrm{A}=$ Angus, $\mathrm{Ch}=$ Charolais, $\mathrm{So}=$ Shorthorn, $\mathrm{Ga}=$ Galloway, $\mathrm{Lh}=$ Longhorn, $\mathrm{Ne}=$ Nellore, $\mathrm{Pd}=$ Piedmontese, $\mathrm{Sa}=$ Salers.

$40 \mathrm{~kg}$. Cows with 1980s Hereford sires also were consistently heavier (44 to $57 \mathrm{~kg}$ ) than cows with reference Hereford sires $(P<0.01)$, which represents an increase in cow weight within the Hereford breed. The corresponding estimates for Angus were also positive but significant only to $4 \mathrm{yr}$ of age (22 to $24 \mathrm{~kg}$ ). On average, cows with 1980s Hereford sires were 10 to $43 \mathrm{~kg}$ heavier than cows with 1980s Angus sires. That difference tended to increase with age and was significant for 4-yrold cows and highly significant for older cows. However, cows with Angus reference sires were 9 to $12 \mathrm{~kg}$ heavier $(P>0.05)$ than cows with Hereford reference sires, a result that is consistent with a greater increase in cow weight within the Hereford breed than within the Angus breed. Previous results have indicated earlier maturing patterns in Angus than in Hereford (Smith et al., 1976). The bulls sampled for this experiment relied heavily on bulls available from the AI industry, especially the Angus bulls. Curve bender (e.g., increased weaning or yearling weights without a proportional increase in mature weight) bulls may have been identified with greater precision and more intensely selected in the Angus breed than in the Hereford breed by the AI industry. Thallman et al. (1999) reported 550-d weights of heifers from Cycle IV. In general, their results agreed with the present study. The ranking of breed groups was the same, except that heifers with Salers sires were slightly heavier than heifers with Shorthorn sires. On average, heifers with Piedmontese, Galloway, and Longhorn sires were 13, 20, and $44 \mathrm{~kg}$ lighter than HA heifers at $550 \mathrm{~d}$. The crossbred heifers with Nellore, Charolais, Salers, and Shorthorn sires were 7, 27, 29, and $32 \mathrm{~kg}$ heavier than HA heifers. Heifers with Angus dams were $4 \mathrm{~kg}$ heavier than heifers out of Hereford dams.

Literature reports for weights at 2 to $6 \mathrm{yr}$ of age for Angus and Hereford cows were reviewed by Arango et al. (2002b). The averages are less than those reported in this study. For crossbred cows from some of the breeds of sire used in this study, Jeffery and Berg (1972) compared two breeding systems in Alberta, Canada: 1) using only British genes (Hereford and Angus-Galloway) and 2) using a hybrid of British with continental breed crosses (Charolais-Angus, Charolais-Galloway). The difference was $22 \mathrm{~kg}$ at the average age, when the hybrid cross cows were heavier $(550 \mathrm{~kg})$ at $4.7 \mathrm{yr}$ than the British cross cows (528 kg at $5.8 \mathrm{yr}$ ). Smith et al. (1976) reported weights of reciprocal HA females and cows with Shorthorn sires raised in Nebraska. On average, the reciprocal HA females were 6 and $3 \%$ heavier than the average of the purebreds at $550 \mathrm{~d}$ and $3 \frac{1}{3} \mathrm{yr}$ of age, respectively. That result is similar to the 4 and $3 \%$ obtained here at 2 and $3 \mathrm{yr}$ of age. They also reported that cows with Shorthorn sires (Angus and Hereford dams) were, on average, only 7 and $9 \mathrm{~kg}$ lighter than HA females at the same ages. Spelbring et al. (1977) reported from a diallel experiment involving Angus and Milking Shorthorn in Indiana that Shorthorn-Angus cows were 14, 20, and $15 \mathrm{~kg}$ heavier than Angus cows at 3 to $5 \mathrm{yr}$ of age. Bowden (1980) compared a sample of 
Table 4. Contrasts between solutions for breed groups $( \pm \mathrm{SE})$, estimates of standard deviations (SD) from estimates of variance components, and estimates of heritability for weight $(\mathrm{kg})$ by age of cow

\begin{tabular}{|c|c|c|c|c|c|}
\hline $\begin{array}{l}\text { Breed } \\
\text { group }^{b}\end{array}$ & \multicolumn{5}{|c|}{ Age of cow, $\mathrm{yr}^{\mathrm{a}}$} \\
\hline $\mathrm{HA}-\mathrm{x}^{\mathrm{c}}$ & 0.00 & 0.00 & 0.00 & 0.00 & 0.00 \\
\hline Ch-x & $31.54 \pm 8.80 * *$ & $47.30 \pm 10.41^{* *}$ & $52.30 \pm 11.32^{* *}$ & $76.24 \pm 13.22 * *$ & $71.59 \pm 15.77^{* *}$ \\
\hline Lh-x & $-61.88 \pm 7.47 * *$ & $-72.51 \pm 8.83^{* *}$ & $-71.62 \pm 9.60^{* *}$ & $-43.66 \pm 10.98^{* *}$ & $-38.96 \pm 11.63 * *$ \\
\hline Sa-x & $11.56 \pm 7.47$ & $8.80 \pm 8.85$ & $7.85 \pm 9.52$ & $23.98 \pm 10.95^{*}$ & $35.59 \pm 11.55^{* *}$ \\
\hline Ga-x & $-37.86 \pm 7.55^{* *}$ & $-39.83 \pm 8.92^{* *}$ & $-40.52 \pm 9.68^{* *}$ & $-24.55 \pm 11.18^{*}$ & $-16.83 \pm 11.64$ \\
\hline So-x & $15.38 \pm 7.86$ & $19.07 \pm 9.30^{*}$ & $20.69 \pm 10.00 *$ & $40.07 \pm 11.97^{* *}$ & $39.60 \pm 12.53^{* *}$ \\
\hline $\operatorname{Ref}(\mathrm{H}, \mathrm{A})-\mathrm{p}^{\mathrm{d}}$ & $\begin{array}{c}18.75 \pm 6.04^{* * *} \\
(4.35)\end{array}$ & $\begin{array}{c}16.81 \pm 7.27^{*} \\
(3.42)\end{array}$ & $\begin{array}{c}17.21 \pm 7.60^{*} \\
(3.36)\end{array}$ & $\begin{array}{c}14.90 \pm 8.85 \\
(2.84)\end{array}$ & $\begin{array}{c}5.27 \pm 8.91 \\
(0.99)\end{array}$ \\
\hline $80(\mathrm{H}, \mathrm{A})-\mathrm{p}^{\mathrm{e}}$ & $\begin{array}{c}5.62 \pm 8.31 \\
(1.19)\end{array}$ & $\begin{array}{c}11.23 \pm 9.89 \\
(2.10)\end{array}$ & $\begin{array}{c}8.91 \pm 10.58 \\
(1.60)\end{array}$ & $\begin{array}{c}-5.74 \pm 12.60 \\
(-1.02)\end{array}$ & $\begin{array}{c}-15.57 \pm 12.54 \\
(-2.72)\end{array}$ \\
\hline $\operatorname{Ref}(\mathrm{H}-\mathrm{A})^{\mathrm{j}}$ & $-9.80 \pm 8.17$ & $-11.47 \pm 9.55$ & $-9.39 \pm 10.32$ & $-10.59 \pm 11.31$ & $-12.18 \pm 12.09$ \\
\hline $\mathrm{Ax}-\mathrm{Hx}^{\mathrm{k}}$ & $4.43 \pm 1.68^{*}$ & $3.41 \pm 1.99^{*}$ & $2.18 \pm 2.13$ & $7.94 \pm 2.45^{* *}$ & $3.44 \pm 2.68$ \\
\hline \multicolumn{6}{|l|}{$\mathrm{SD}^{1}$} \\
\hline$\sigma_{\mathrm{p}}$ & 54.37 & 52.00 & 53.78 & 54.33 & 52.49 \\
\hline$\sigma_{\mathrm{g}}$ & 37.12 & 31.77 & 36.36 & 33.67 & 37.84 \\
\hline$\sigma_{\mathrm{c}}$ & 23.01 & 29.29 & 27.03 & 33.58 & 19.69 \\
\hline $\mathrm{h}^{2}$ & 0.46 & 0.37 & 0.46 & 0.38 & 0.52 \\
\hline
\end{tabular}

${ }^{a}$ Means in the contrast are different: $* * P<0.01$ or $* P<0.05$.

${ }^{b_{-x}}=$ crosses, $\mathrm{H}=$ Hereford, A = Angus, HA = reciprocal crosses of AH and HA, Ch = Charolais, Lh = Longhorn, Sa $=$ Salers, Ga $=$ Galloway, $\mathrm{Ne}=$ Nellore, $\mathrm{Pd}=$ Piedmontese, So $=$ Shorthorn .

${ }^{\mathrm{c} C o n t r a s t s: ~ r e s p e c t i v e ~ b r e e d ~ o f ~ s i r e ~ g r o u p ~ v s . ~ H e r e f o r d-A n g u s ~ c r o s s e s ~(H A-x) ~ w i t h ~ H, ~ A ~} 1980$ sires.

${ }^{\mathrm{d}}$ Contrast: H-A pure breeds vs. HA-x (reference sires); in parentheses, the heterosis percentages.

'Contrast: H-A pure breeds vs. HA-x (1980's sires); in parentheses, the heterosis percentages.

${ }^{\mathrm{f}}$ Contrast: $0.25\{(\mathrm{HA} 80 \mathrm{~s}+\mathrm{H} 80 \mathrm{~s}+\mathrm{A} 80 \mathrm{~s}+\mathrm{AH} 80 \mathrm{~s})-($ HAref + Href + Aref + AHref $)\}$.

gContrast: $0.50\{(\mathrm{HA} 80 \mathrm{~s}+\mathrm{H} 80 \mathrm{~s})-($ HAref + Href $)\}$.

${ }^{\mathrm{h}}$ Contrast: $0.50\{(\mathrm{AH} 80 \mathrm{~s}+\mathrm{A} 80 \mathrm{~s})-(\mathrm{AHref}+\mathrm{Aref})\}$.

${ }^{\mathrm{i}}$ Contrast: $0.50\{(\mathrm{HA} 80 \mathrm{~s}+\mathrm{H} 80 \mathrm{~s})-(\mathrm{AH} 80 \mathrm{~s}+\mathrm{A} 80 \mathrm{~s})\}$.

${ }^{\mathrm{j} C o n t r a s t:} 0.50\{($ HAref + Href $)-($ AHref + Aref $)\}$.

${ }^{\mathrm{k}}$ Contrast: crosses with Hereford dams vs. crosses with Angus dams.

${ }^{\mathrm{l}} \sigma_{\mathrm{p}}=$ phenotypic standard deviation, $\sigma_{\mathrm{g}}=$ genetic standard deviation, and $\sigma_{\mathrm{c}}=$ permanent environmental standard deviation, derived from variance component estimates; $h^{2}=$ heritability.

HA and $F_{1}$ cows with Charolais, Jersey, and Simmental sires and Angus dams transferred from the GPE Program to Alberta, Canada. The Charolais-Angus cows were $53 \mathrm{~kg}$ heavier than HA cows at $2 \mathrm{yr}$ of age. Nadarajah et al. (1984) reported that Charolais-Angus cows were $47,58,68$, and $57 \mathrm{~kg}$ heavier from 3 to $6 \mathrm{yr}$ of age than Angus cows. Montaño-Bermudez (1987) compared HA (low milking), Red Poll-Angus (medium milking), and Shorthorn-Angus (high milking) cows in a study comparing crosses with differing potentials for milk production. Cows with Shorthorn sires were lighter than HA cows at 2, 3, and $4 \mathrm{yr}$ of age, in contrast to this study, but in agreement with Smith et al. (1976). Sacco et al. (1990) from a five-breed diallel (Angus, Brahman, Hereford, Holstein, and Jersey) experiment in Texas, reported that HA cows, on average, were 3.6\% heavier than purebred Angus and Hereford at 2 and 3 $\mathrm{yr}$, similar to the 3.4 and $2.1 \%$ at $3 \mathrm{yr}$ in this study for reference and 1980s sires, respectively. The cows with Brahman sires were heaviest, averaging $44 \mathrm{~kg}$ more than HA cows. That difference was greater than for cows sired by the Bos indicus sire breed used here (Nellore), which were lighter than HA by $7 \mathrm{~kg}$ at $3 \mathrm{yr}$ of age.

Estimates of breed-group contrasts for weight adjusted for condition score are given in Table 5 . Rankings of crossbred cows were the same as for actual weight, although breed differences (and significance levels) differed somewhat. Cows with Charolais and Shorthorn sires were consistently heavier $(P<0.01)$ than HA cows at every age, ranging from $22 \mathrm{~kg}$ for Shorthorn crosses at $2 \mathrm{yr}$ of age to $72 \mathrm{~kg}$ for Charolais crosses at $5 \mathrm{yr}$ of age. Cows with Salers sires were heavier than HA cows, but the difference was significant only at $5(P<0.05)$ and $6(P<0.01) \mathrm{yr}$ of age. As for actual weight, cows with Nellore sires did not differ significantly from HA cows. Cows with Longhorn, Galloway, and Piedmontese sires were consistently lighter than HA cows by differences that ranged from 14 (Piedmontese at $6 \mathrm{yr}$ ) to 59 $\mathrm{kg}$ (Longhorn at $3 \mathrm{yr}$ ) and that were highly significant, 
Table 5. Contrasts between solutions for breed-groups $( \pm \mathrm{SE})$, estimates of standard deviations (SD) from estimates of variance components, and estimates of heritability for weight adjusted for condition score $(\mathrm{kg})$ by age of cow

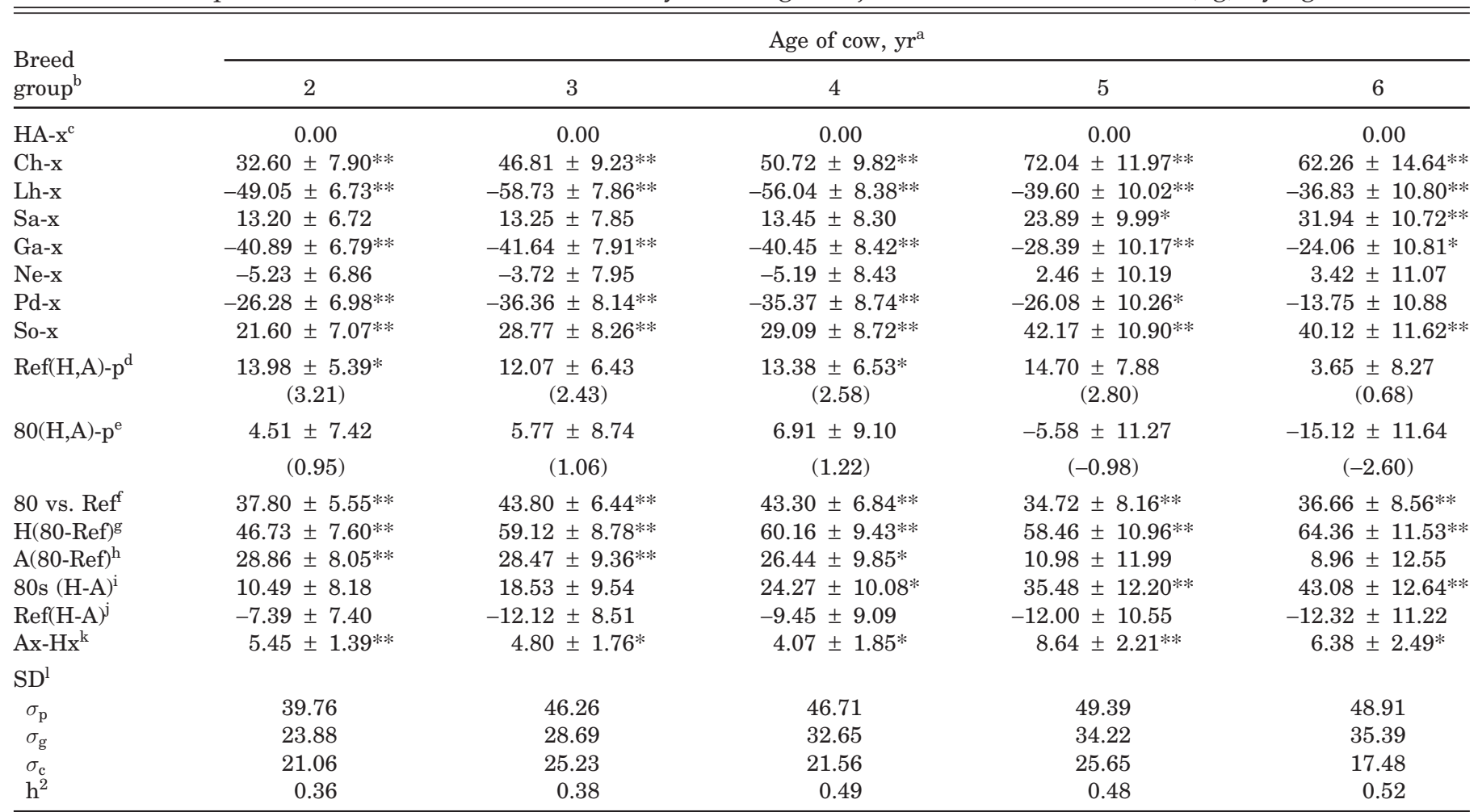

${ }^{a}$ Means in the contrast are different: $* * P<0.01$ or $* P<0.05$.

$\mathrm{b}_{-\mathrm{x}}=$ crosses, $\mathrm{H}=$ Hereford, $\mathrm{A}=$ Angus, $\mathrm{HA}=$ reciprocal crosses of $\mathrm{AH}$ and HA, Ch = Charolais, Lh = Longhorn, Sa = Salers, Ga $=\mathrm{Galloway}$, $\mathrm{Ne}=$ Nellore, $\mathrm{Pd}=$ Piedmontese, So $=$ Shorthorn .

${ }^{\mathrm{c} C o n t r a s t s:}$ respective breed of sire group vs. Hereford-Angus crosses (HA-x) with H, A 1980 sires.

${ }^{\mathrm{d} C o n t r a s t: ~ H-A}$ pure breeds vs. HA-x (reference sires); in parentheses, the heterosis percentages.

eContrast: H-A pure breeds vs. HA-x (1980's sires); in parentheses, the heterosis percentages.

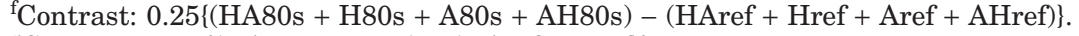

${ }^{\mathrm{g}}$ Contrast: $0.50\{(\mathrm{HA} 80 \mathrm{~s}+\mathrm{H} 80 \mathrm{~s})-($ HAref + Href $)\}$.

${ }^{\mathrm{h}}$ Contrast: $0.50\{(\mathrm{AH} 80 \mathrm{~s}+\mathrm{A} 80 \mathrm{~s})-(\mathrm{AHref}+\mathrm{Aref})\}$.

${ }^{\mathrm{i}}$ Contrast: $0.50\{(\mathrm{HA} 80 \mathrm{~s}+\mathrm{H} 80 \mathrm{~s})-(\mathrm{AH} 80 \mathrm{~s}+\mathrm{A} 80 \mathrm{~s})\}$.

${ }^{\mathrm{j} C o n t r a s t:}$ 0.50\{(HAref + Href) $-($ AHref + Aref) $)$.

${ }^{\mathrm{k}}$ Contrast: crosses with Hereford dams vs. crosses with Angus dams.

${ }_{\sigma_{\mathrm{p}}}=$ phenotypic standard deviation, $\sigma_{\mathrm{g}}=$ genetic standard deviation, and $\sigma_{\mathrm{c}}=$ permanent environmental standard deviation, derived from variance component estimates; $\mathrm{h}^{2}=$ heritability.

except for Piedmontese at $5 \mathrm{yr}$ and Galloway at $6 \mathrm{yr}(P$ $<0.05)$ and Piedmontese at 6 yr $(P>0.05)$.

The reciprocal HA cows, with reference sires, were heavier than the average of the purebred Hereford and Angus cows by differences of 4 to $15 \mathrm{~kg}$, but the differences were significant only at 2 and 4 yr of age. Estimates of direct heterosis were between 2 and $3 \%$, except at $6 \mathrm{yr}$ of age when the estimate was 1\%. The corresponding differences for cows with 1980s sires were less and were not significant at any age.

Cows with 1980s Hereford and Angus sires, averaged over straightbred and crossbred matings, were consistently heavier $(P<0.01)$ than cows with Hereford and Angus reference sires, by differences that ranged from 35 to $44 \mathrm{~kg}$. Cows with 1980s Hereford sires also were consistently heavier ( 47 to $64 \mathrm{~kg}$ ) than cows with reference Hereford sires $(P<0.01)$, which represents a positive trend for cow weight adjusted for condition score within the Hereford breed. The corresponding estimates for Angus were also positive for the 1980s sires but were significant only up to $4 \mathrm{yr}$ of age. On average, cows with 1980s Hereford sires were 10 to $43 \mathrm{~kg}$ heavier than cows with 1980s Angus sires. The differences tended to increase with age and were significant for 4yr-old and highly significant for older cows. Cows with Angus reference sires were 7 to $12 \mathrm{~kg}$ heavier $(P>$ 0.05 ) than cows with reference Hereford sires, which is consistent with a greater trend for increased cow weight within the Hereford breed than within the Angus breed. Cows with Hereford dams averaged 4 to $9 \mathrm{~kg}$ lighter than cows with Angus dams with differences that were highly significant at 2 and $5 \mathrm{yr}$ and significant at other ages.

Smith et al. (1976) reported that reciprocal HA cows at 6 to $9 \mathrm{yr}$ of age were $2 \%$ heavier than the average of the purebreds, a difference that was greater than the corresponding differences in this study at $6 \mathrm{yr}$ of age. Nadarajah et al. (1984) found that Charolais-Angus cows were 61 to $77 \mathrm{~kg}$ heavier than purebred cows at 3 to $6 \mathrm{yr}$ of age. 
Table 6. Estimates of breed-group means for hip height $(\mathrm{cm})$ by age at measurement ${ }^{\mathrm{a}}$

\begin{tabular}{lccccc}
\hline \hline & \multicolumn{4}{c}{ Age of cow, yr } \\
\cline { 2 - 5 } Breed $^{\text {broup }}$ & 2 & 3 & 4 & 5 & 6 \\
\hline H reference & 124 & 127 & 127 & 126 & 127 \\
A reference & 124 & 127 & 127 & 126 & 126 \\
H 1980s & 131 & 134 & 134 & 133 & 134 \\
A 1980s & 130 & 132 & 132 & 131 & 130 \\
HA reference & 126 & 128 & 128 & 127 & 127 \\
AH reference & 125 & 128 & 128 & 127 & 126 \\
HA 1980s & 131 & 134 & 134 & 133 & 133 \\
AH 1980s & 129 & 131 & 131 & 129 & 138 \\
Ch-H & 135 & 139 & 139 & 138 & 138 \\
Ch-A & 136 & 140 & 139 & 139 & 136 \\
So-H & 134 & 137 & 136 & 136 \\
So-A & 134 & 137 & 137 & 127 & 127 \\
Ga-H & 126 & 129 & 129 & 128 & 128 \\
Ga-A & 126 & 129 & 129 & 131 & 131 \\
Lh-H & 130 & 133 & 132 & 130 & 130 \\
Lh-A & 129 & 131 & 131 & 139 & 139 \\
Ne-H & 136 & 139 & 140 & 138 & 138 \\
Ne-A & 136 & 139 & 140 & 131 & 132 \\
Pd-H & 130 & 133 & 132 & 130 & 130 \\
Pd-A & 130 & 132 & 132 & 136 & 136 \\
Sa-H & 133 & 136 & 137 & & 137 \\
Sa-A & 135 & 137 & & & \\
\hline
\end{tabular}

${ }^{a}$ Means were obtained by adding the unadjusted mean for HA cows, the solution constrained to zero, to the solution for each breed-group.

${ }^{b}$ Reference sires born from 1962 through 1970; 1980s = sires born from 1980 through 1987; H = Hereford, $\mathrm{A}=$ Angus, $\mathrm{Ch}=$ Charolais, $\mathrm{So}=$ Shorthorn, $\mathrm{Ga}=$ Galloway, $\mathrm{Lh}=$ Longhorn, $\mathrm{Ne}=$ Nellore, $\mathrm{Pd}=$ Piedmontese, $\mathrm{Sa}=$ Salers.

\section{Cow Height}

Table 6 lists estimates of breed means for height by age of cows. On average, cows of all breed groups gained only 1 to $4 \mathrm{~cm}$ of stature from 2 to $6 \mathrm{yr}$, reaching a maximum height at $3 \mathrm{yr}$ of age and 97 to $99 \%$ of their final height by 2 yr. This pattern indicates that cows reached maturity for stature earlier than for weight, as in Cycles I, II, and III (Arango et al., 2002b,c,d). On average, cows with Nellore and Charolais sires were tallest at every age and interchanged rank order from age to age $(136 \mathrm{~cm}$ at $2 \mathrm{yr}$ and $140 \mathrm{~cm}$ for Nellore at 4 yr). The second tallest group included cows with Shorthorn and Salers sires, which tended to have similar heights (134 to $137 \mathrm{~cm}$ ). The next group included HA cows with 1980s sires and cows with Piedmontese and Longhorn sires (130 to $133 \mathrm{~cm}$ ). The Galloway cross $(126$ to $129 \mathrm{~cm})$ and HA cows with reference sires (126 to $128 \mathrm{~cm}$ ) were the smallest cows. Cows with Nellore sires were taller than the Angus cows with reference sires by 12 to $13 \mathrm{~cm}$ at each age. A similar pattern was found for Brahman cross cows in Cycle III (Arango et al., 2002d), indicating that heterosis from Bos taurusBos indicus crosses for stature may be relatively important.

Estimates of breed-group contrasts are in Table 7 . Cows with Charolais, Salers, Nellore, and Shorthorn sires were taller than 1980s HA cows at all ages $(P<$ 0.01 ) by differences that ranged from 4 to $7 \mathrm{~cm}$. Cows with Longhorn and Piedmontese sires were less than
$1 \mathrm{~cm}$ shorter than HA cows. The differences were not significant at any age. Cows with Galloway sires were exceeded by HA cows by approximately $4 \mathrm{~cm}(P<0.01)$. In general, breed group means for cow height followed a trend similar to that for means for weight. The only remarkable difference was for cows with Bos indicus sires (Nellore), which, although intermediate for weight (i.e., did not differ significantly from HA), were even taller than cows sired by Charolais bulls (the heaviest cows) at all ages.

On average, HA cows with reference sires were approximately $1 \mathrm{~cm}$ taller than the purebred (Hereford, Angus) cows until $5 \mathrm{yr}$ of age, but the differences were significant only at 2 and $3 \mathrm{yr}$ of age. Estimates of direct heterosis were less than $1 \%$ at each age. The corresponding estimates were even less for cows with 1980s sires and were close to zero $(P>0.05)$ at all ages. Cows with 1980s Hereford and Angus sires, averaged over straightbred and crossbred matings, were 5 to $6 \mathrm{~cm}$ taller $(P<0.01)$ than cows with reference Hereford and Angus sires at each age. Cows with 1980s Hereford sires also were consistently taller $(5$ to $7 \mathrm{~cm}$ ) than cows with reference Hereford sires $(P<0.01)$. This difference represents an increase for cow height within the Hereford breed. The corresponding estimates for Angus were also positive $(P<0.01)$ but were less $(4$ to $6 \mathrm{~cm})$. On average, cows with 1980s Hereford sires were taller than cows with 1980s Angus sires by differences that tended to increase with age and that were significant for 3-yr-old and highly significant for older cows. Cows 
Table 7. Contrasts between solutions for breed groups ( $\pm \mathrm{SE}$ ), estimates of standard deviations (SD) from estimates of variance components, and estimates of heritability for hip height $(\mathrm{cm})$ by age of cow

\begin{tabular}{|c|c|c|c|c|c|}
\hline \multirow{2}{*}{$\begin{array}{l}\text { Breed } \\
\text { group }^{b}\end{array}$} & \multicolumn{5}{|c|}{ Age of cow, $\mathrm{yr}^{\mathrm{a}}$} \\
\hline & 2 & 3 & 4 & 5 & 6 \\
\hline $\mathrm{HA}-\mathrm{x}^{\mathrm{c}}$ & 0.00 & 0.00 & 0.00 & 0.00 & 0.00 \\
\hline Ch-x & $5.40 \pm 0.78^{* *}$ & $6.53 \pm 0.81^{* *}$ & $6.40 \pm 0.81^{* *}$ & $7.36 \pm 0.94 * *$ & $6.43 \pm 1.21^{* *}$ \\
\hline Lh-x & $-0.96 \pm 0.68$ & $-0.56 \pm 0.70$ & $-0.82 \pm 0.71$ & $-0.44 \pm 0.80$ & $-0.54 \pm 0.90$ \\
\hline Sa-x & $3.67 \pm 0.68^{* *}$ & $4.06 \pm 0.71^{* *}$ & $3.93 \pm 0.70^{* *}$ & $4.64 \pm 0.80^{* *}$ & $4.82 \pm 0.89 * *$ \\
\hline Ga-x & $-4.45 \pm 0.68^{* *}$ & $-3.81 \pm 0.70^{* *}$ & $-3.72 \pm 0.70^{* *}$ & $-3.88 \pm 0.81^{* *}$ & $-3.90 \pm 0.90^{* *}$ \\
\hline $\mathrm{Ne}-\mathrm{x}$ & $5.84 \pm 0.70^{* *}$ & $6.60 \pm 0.72^{* *}$ & $7.25 \pm 0.71^{* *}$ & $7.12 \pm 0.82^{* *}$ & $6.86 \pm 0.92^{* *}$ \\
\hline $\mathrm{Pd}-\mathrm{x}$ & $-0.35 \pm 0.71$ & $-0.59 \pm 0.74$ & $-0.85 \pm 0.75$ & $-0.90 \pm 0.83$ & $-0.16 \pm 0.92$ \\
\hline So-x & $3.63 \pm 0.71^{* *}$ & $4.33 \pm 0.74^{* *}$ & $3.96 \pm 0.73^{* *}$ & $4.54 \pm 0.87^{* *}$ & $4.51 \pm 0.96^{* *}$ \\
\hline $\operatorname{Ref}(\mathrm{H}, \mathrm{A})-\mathrm{p}^{\mathrm{d}}$ & $\begin{array}{c}1.04 \pm 0.50^{*} \\
(0.83)\end{array}$ & $\begin{array}{c}1.11 \pm 0.51^{*} \\
(0.87)\end{array}$ & $\begin{array}{c}0.95 \pm 0.51 \\
(0.75)\end{array}$ & $\begin{array}{c}0.80 \pm 0.59 \\
(0.63)\end{array}$ & $\begin{array}{c}0.36 \pm 0.66 \\
(0.28)\end{array}$ \\
\hline $80(\mathrm{H}, \mathrm{A})-\mathrm{p}^{\mathrm{e}}$ & $\begin{array}{c}0.14 \pm 0.69 \\
(0.11)\end{array}$ & $\begin{array}{c}-0.46 \pm 0.72 \\
(-0.35)\end{array}$ & $\begin{array}{c}-0.07 \pm 0.71 \\
(-0.05)\end{array}$ & $\begin{array}{c}-0.62 \pm 0.85 \\
(-0.47)\end{array}$ & $\begin{array}{c}-0.71 \pm 0.94 \\
(-0.54)\end{array}$ \\
\hline 80 vs. $\operatorname{Ref}^{f}$ & $5.68 \pm 0.58^{* *}$ & $5.60 \pm 0.60^{* *}$ & $5.53 \pm 0.59 * *$ & $5.16 \pm 0.67^{* *}$ & $5.30 \pm 0.72^{* *}$ \\
\hline $\mathrm{H}(80-\mathrm{Ref})^{\mathrm{g}}$ & $5.13 \pm 0.81^{* *}$ & $6.48 \pm 0.83^{* *}$ & $6.74 \pm 0.83^{* *}$ & $6.59 \pm 0.90 * *$ & $6.51 \pm 0.97^{* *}$ \\
\hline$A(80-\operatorname{Ref})^{h}$ & $6.24 \pm 0.82$ & $4.72 \pm 0.85^{* *}$ & $4.32 \pm 0.84 * *$ & $3.73 \pm 0.97 * *$ & $4.10 \pm 1.06^{* *}$ \\
\hline $80 \mathrm{~s}(\mathrm{H}-\mathrm{A})^{\mathrm{i}}$ & $1.52 \pm 0.81$ & $1.79 \pm 0.84^{*}$ & $2.52 \pm 0.84^{* *}$ & $2.93 \pm 0.96^{* *}$ & $3.29 \pm 1.05^{* *}$ \\
\hline $\operatorname{Ref}(\mathrm{H}-\mathrm{A})^{\mathrm{j}}$ & $0.41 \pm 0.80$ & $0.04 \pm 0.83$ & $0.10 \pm 0.82$ & $0.08 \pm 0.89$ & $0.89 \pm 0.97$ \\
\hline $\mathrm{Ax}-\mathrm{Hx}^{\mathrm{k}}$ & $0.57 \pm 0.15^{* *}$ & $0.43 \pm 0.15^{*}$ & $0.56 \pm 0.15^{* *}$ & $0.44 \pm 0.17^{*}$ & $-0.09 \pm 0.20$ \\
\hline \multicolumn{6}{|l|}{$\mathrm{SD}^{1}$} \\
\hline$\sigma_{\mathrm{p}}$ & 3.92 & 3.98 & 3.78 & 3.94 & 3.91 \\
\hline$\sigma_{\mathrm{g}}$ & 3.15 & 3.32 & 3.27 & 3.34 & 3.33 \\
\hline$\sigma_{\mathrm{c}}$ & 0.02 & 0.01 & 0.01 & 0.02 & 0.02 \\
\hline $\mathrm{h}^{2}$ & 0.64 & 0.70 & 0.64 & 0.72 & 0.73 \\
\hline
\end{tabular}

\footnotetext{
${ }^{\text {a }}$ Means in the contrast are different: $* * P<0.01$ or $* P<0.05$.

${ }^{\mathrm{b}}-\mathrm{x}=$ crosses, $\mathrm{H}=$ Hereford, $\mathrm{A}=$ Angus, $\mathrm{HA}=$ reciprocal crosses of $\mathrm{AH}$ and $\mathrm{HA}, \mathrm{Ch}=$ Charolais, $\mathrm{Lh}=$ Longhorn, $\mathrm{Sa}=$ Salers, $\mathrm{Ga}=$ Galloway, $\mathrm{Ne}=$ Nellore, $\mathrm{Pd}=$ Piedmontese, So $=$ Shorthorn .

${ }^{\mathrm{c}}$ Contrasts: respective breed of sire group vs. Hereford-Angus crosses (HA-x) with H, A 1980 sires.

${ }^{\mathrm{d}}$ Contrast: H-A pure breeds vs. HA-x (reference sires); in parentheses, the heterosis percentages.

'Contrast: H-A pure breeds vs. HA-x (1980's sires); in parentheses, the heterosis percentages.

${ }^{\mathrm{f}}$ Contrast: $0.25\{(\mathrm{HA} 80 \mathrm{~s}+\mathrm{H} 80 \mathrm{~s}+\mathrm{A} 80 \mathrm{~s}+\mathrm{AH} 80 \mathrm{~s})-($ HAref + Href + Aref + AHref $)\}$.

${ }^{g}$ Contrast: $0.50\{(\mathrm{HA} 80 \mathrm{~s}+\mathrm{H} 80 \mathrm{~s})-($ HAref + Href $)\}$.

${ }^{\mathrm{h}}$ Contrast: $0.50\{(\mathrm{AH} 80 \mathrm{~s}+\mathrm{A} 80 \mathrm{~s})-($ AHref + Aref $)\}$.

${ }^{\mathrm{i} C o n t r a s t:} 0.50\{(\mathrm{HA} 80 \mathrm{~s}+\mathrm{H} 80 \mathrm{~s})-(\mathrm{AH} 80 \mathrm{~s}+\mathrm{A} 80 \mathrm{~s})\}$.

${ }^{\mathrm{j} C o n t r a s t:}$ 0.50\{(HAref + Href) $-($ AHref + Aref $\left.)\right\}$.

${ }^{\mathrm{k}}$ Contrast: crosses with Hereford dams vs. crosses with Angus dams.

${ }^{1} \sigma_{\mathrm{p}}=$ phenotypic standard deviation, $\sigma_{\mathrm{g}}=$ genetic standard deviation, and $\sigma_{\mathrm{c}}=$ permanent environmental standard deviation, derived from variance component estimates; $\mathrm{h}^{2}=$ heritability.
}

with Hereford and Angus reference sires had approximately the same height $(P>0.05)$ at all ages. Cows with Angus dams were slightly, but significantly, taller than cows with Hereford dams until 5 yr of age. At 6 yr of age, they were not significantly different for height.

A previous report from USMARC presented heights of Cycle IV heifers at $550 \mathrm{~d}$ of age (Thallman et al., 1999) and, on average, they were 2 to $4 \mathrm{~cm}$ less than for 2-yr-old cows in the present study, as expected for younger females. Rankings of crossbred females were the same in that study and the current study. Gregory et al. $(1992,1995)$ reported heights of purebred and composite cows from 2 to $7+$ yr of age from the GPU Project at USMARC. Means for height ranged from 124 to $129 \mathrm{~cm}$ for Herefords and from 123 to $127 \mathrm{~cm}$ for Angus, similar to the means for cows from reference sires of the same breeds in this study. Means for height were summarized from literature by Arango et al. (2002b) and averaged 118, 121, 123, and $123 \mathrm{~cm}$, respec- tively, for Angus cows from 2 to 5 yr of age, which, although smaller, followed the same general pattern as in this study. For Hereford cows, Brown et al. (1956) reported heights of 118 to $123 \mathrm{~cm}$ at 2 to $7 \mathrm{yr}$ of age, Brown and Franks (1964) found a mean height of 120 $\mathrm{cm}$ at $3 \mathrm{yr}$, and Sacco et al. (1990) reported a mean of $122 \mathrm{~cm}$ at $2.4 \mathrm{yr}$ of age. In general, those heights are less than the heights in the current study. In Australia, Polled Hereford cows were 129, 130, and $130 \mathrm{~cm}$ tall at 3+, 4+, and 5+ yr of age, respectively, (Meyer, 1995), which are intermediate between the heights for cows from reference and 1980s sires in this study. From a study conducted in Texas, reciprocal HA cows were, on average, $2 \mathrm{~cm}$ taller than purebred Hereford and Angus cows between 2 and 3 yr of age (Sacco et al., 1990). The Brahman-cross cows were $10 \mathrm{~cm}$ taller than HA, similar to the cows with Nellore sires in this study, which were 6 to $7 \mathrm{~cm}$ taller than HA. In a Canadian study, Jeffery and Berg (1972), Charolais-Angus and Charolais-Gallo- 
Table 8. Estimates of breed-group means for body condition score (points) by age at measurement ${ }^{\mathrm{a}}$

\begin{tabular}{|c|c|c|c|c|c|}
\hline \multirow{2}{*}{$\begin{array}{l}\text { Breed } \\
\text { group }^{b}\end{array}$} & \multicolumn{5}{|c|}{ Age of cow, yr } \\
\hline & 2 & 3 & 4 & 5 & 6 \\
\hline $\mathrm{H}$ reference & 6.2 & 6.4 & 6.3 & 6.7 & 6.8 \\
\hline A reference & 6.4 & 6.3 & 6.3 & 6.5 & 6.8 \\
\hline H 1980s & 6.2 & 6.2 & 6.2 & 6.5 & 6.8 \\
\hline A $1980 \mathrm{~s}$ & 6.2 & 6.2 & 6.2 & 6.0 & 6.8 \\
\hline HA reference & 6.5 & 6.5 & 6.5 & 6.7 & 6.9 \\
\hline $\mathrm{AH}$ reference & 6.5 & 6.5 & 6.5 & 6.7 & 6.9 \\
\hline HA 1980s & 6.2 & 6.5 & 6.3 & 6.3 & 6.3 \\
\hline AH 1980s & 6.2 & 6.3 & 6.2 & 6.2 & 6.6 \\
\hline $\mathrm{Ch}-\mathrm{H}$ & 6.3 & 6.5 & 6.5 & 6.5 & 6.5 \\
\hline Ch-A & 6.1 & 6.3 & 6.2 & 6.5 & 6.4 \\
\hline So-H & 6.0 & 6.0 & 6.0 & 6.3 & 6.3 \\
\hline So-A & 5.9 & 5.9 & 5.9 & 5.9 & 5.9 \\
\hline Ga-H & 6.4 & 6.5 & 6.3 & 6.6 & 6.5 \\
\hline Ga-A & 6.3 & 6.4 & 6.3 & 6.5 & 6.5 \\
\hline Lh-H & 5.7 & 5.8 & 5.7 & 6.1 & 6.1 \\
\hline Lh-A & 5.6 & 5.8 & 5.6 & 5.9 & 5.9 \\
\hline $\mathrm{Ne}-\mathrm{H}$ & 6.0 & 6.3 & 6.4 & 6.4 & 6.4 \\
\hline $\mathrm{Ne}-\mathrm{A}$ & 6.0 & 6.2 & 6.2 & 6.2 & 6.2 \\
\hline $\mathrm{Pd}-\mathrm{H}$ & 5.9 & 5.9 & 5.7 & 5.9 & 5.9 \\
\hline Pd-A & 6.0 & 5.8 & 5.6 & 5.8 & 5.8 \\
\hline $\mathrm{Sa}-\mathrm{H}$ & 6.2 & 6.3 & 6.1 & 6.3 & 6.3 \\
\hline Sa-A & 6.1 & 6.2 & 6.1 & 6.2 & 6.2 \\
\hline
\end{tabular}

${ }^{a}$ Means were obtained by adding the unadjusted mean for HA cows, the solution constrained to zero, to the solution for each breed-group.

${ }^{\mathrm{b}}$ Reference sires born from 1962 through 1970; 1980s = sires born from 1980 through 1987; H = Hereford, $\mathrm{A}=$ Angus, $\mathrm{Ch}=$ Charolais, $\mathrm{So}=$ Shorthorn, $\mathrm{Ga}=$ Galloway, $\mathrm{Lh}=$ Longhorn, $\mathrm{Ne}=$ Nellore, $\mathrm{Pd}=$ Piedmontese, $\mathrm{Sa}=$ Salers.

way hybrid cows were $4 \mathrm{~cm}$ taller than Hereford-AngusGalloway cows at 2 and 3 to 4 yr of age. Bowden (1980) reported that Charolais-Angus cows $(122 \mathrm{~cm})$ were 5 $\mathrm{cm}$ taller than HA cows at $2 \mathrm{yr}$ of age. Meyer (1995) reported that cows of a synthetic breed called Wokalup, with genes from Charolais, Brahman, Angus, Hereford, and Holstein, were approximately $10 \mathrm{~cm}$ taller than purebred Herefords in Western Australia after $3 \mathrm{yr}$ of age.

\section{Body Condition Score}

Estimates of breed means for body condition score by age of cows are in Table 8. Estimates fell within a narrow range of 5.6 to 6.9 points across ages and breed groups. On average, HA cows with reference sires had the largest scores (6.5 to 6.9) at all ages. The other crossbred groups interchanged rank across ages but, in general, had the following order: Galloway (6.4 to 6.6), Charolais and HA with 1980s sires (6.2 to 6.5), Salers (6.2 to 6.3), Nellore (6.0 to 6.3), Shorthorn (6.0 to 6.1), Piedmontese, and Longhorn (5.7 to 6.0). Purebred Angus and Hereford cows with reference sires had approximately the same condition scores at each age (6.2 to 6.8), which were slightly larger than scores for cows with $1980 \mathrm{~s}$ sires until $5 \mathrm{yr}$ of age (6.0 to 6.5). At $6 \mathrm{yr}$, Hereford and Angus cows from sires of both time periods had the same condition score (6.8).
Estimates of breed-group contrasts for condition score (Table 9) are less consistent than contrasts for the other traits. Cows with Galloway sires were the only group exceeding HA cross cows at all ages, but that superiority was significant at 5 and highly significant at $6(P<0.01)$ yr of age when greater than 0.25 point. Scores of cows with Charolais sires exceeded those of HA cows after $3 \mathrm{yr}$ of age, but the difference was significant only at $6 \mathrm{yr}$ of age (0.41 point). Cows from Salers and Nellore sires were not statistically different from HA cows at any age, except for Nellore at $2 \mathrm{yr}$ of age $(-0.24$ point). Cows with the other breeds of sire had smaller scores than HA cows at all ages with differences that were highly significant ( -0.29 to -0.63 point), except for Longhorn and Shorthorn after $4 \mathrm{yr}$ of age.

Reciprocal HA crosses with reference sires had slightly larger condition scores ( 0.1 to 0.2 point) than the purebred Hereford and Angus cows, but the differences were statistically significant only at $2(P<0.01)$ and $3(P<0.05)$ yr of age. Cows with Hereford and Angus reference sires, averaged over straightbred and crossbred matings, had greater condition scores than cows with 1980s sires at all ages. The differences were highly significant $(P<0.01)$ at 2,5 , and $6 \mathrm{yr}$ of age, when greater than 0.19 point. Cows with reference Hereford sires also had slightly greater condition scores than cows with 1980s Hereford sires. The difference was significant only at older ages ( 5 and $6 \mathrm{yr}$ of age). A similar 
Table 9. Contrasts between solutions for breed-groups $( \pm \mathrm{SE})$, estimates of standard deviations (SD) from estimates of variance components, and estimates of heritability for body condition score (points) by age of measurements

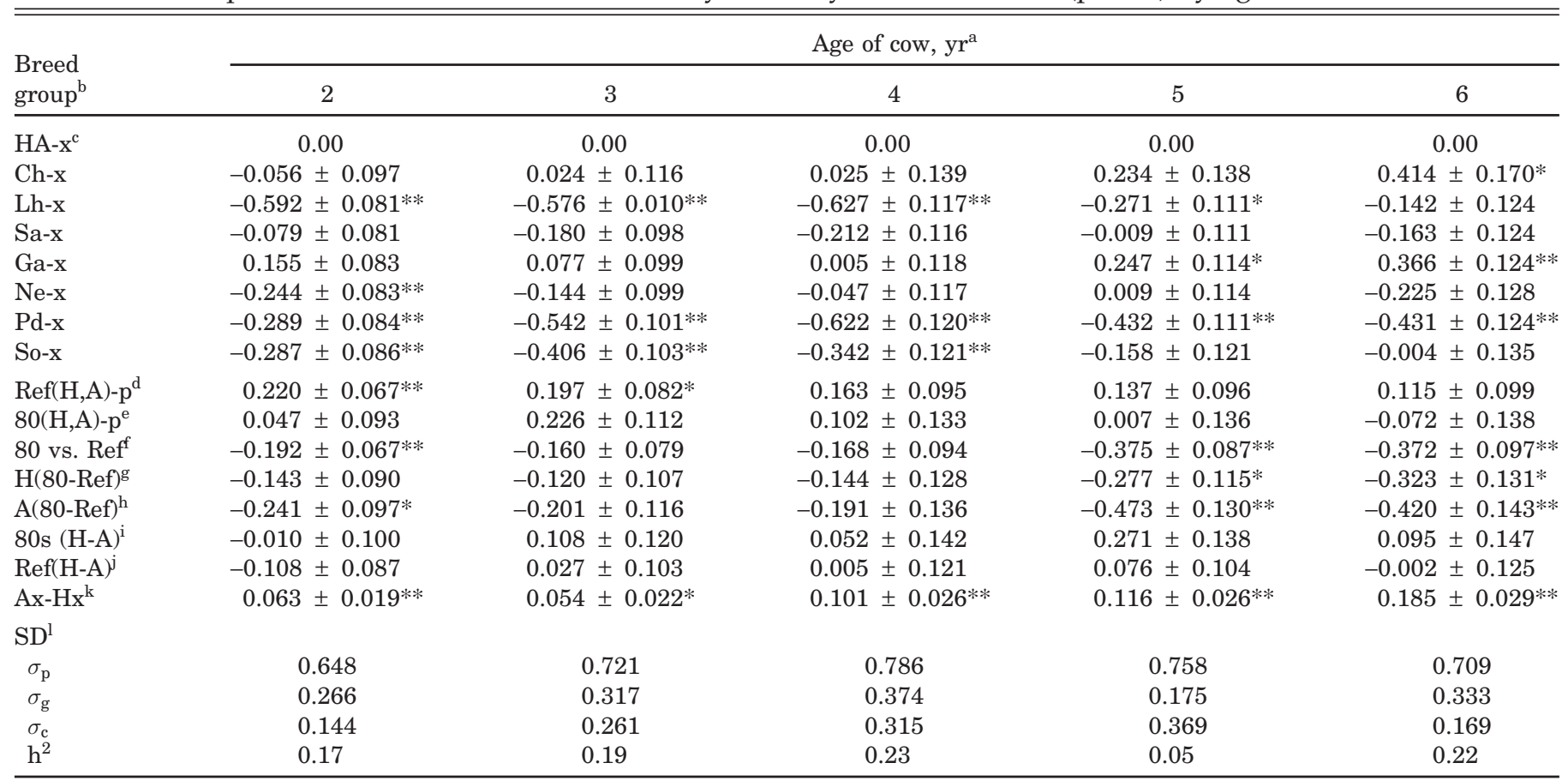

${ }^{\text {a }}$ Means in the contrast are different: $* * P<0.01$ or $* P<0.05$.

${ }^{b_{-x}}=$ crosses, $\mathrm{H}=$ Hereford, A = Angus, HA = reciprocal crosses of AH and HA, Ch = Charolais, Lh = Longhorn, Sa $=$ Salers, Ga $=$ Galloway, $\mathrm{Ne}=$ Nellore, $\mathrm{Pd}=$ Piedmontese, So = Shorthorn .

${ }^{\mathrm{c} C o n t r a s t s:}$ respective breed of sire group vs. Hereford-Angus crosses (HA-x) with H, A 1980 sires.

${ }^{\mathrm{d}}$ Contrast: H-A pure breeds vs. HA-x (reference sires).

${ }^{\mathrm{e} C o n t r a s t: ~ H-A ~ p u r e ~ b r e e d s ~ v s . ~ H A-x ~(1980 s ~ s i r e s) . ~}$

${ }^{f}$ Contrast: $0.25\{($ HA80s + H80s + A80s + AH80s $)-($ HAref + Href + Aref + AHref $)\}$.

${ }^{\mathrm{g}}$ Contrast: $0.50\{(\mathrm{HA} 80 \mathrm{~s}+\mathrm{H} 80 \mathrm{~s})-($ HAref + Href $)\}$.

${ }^{\mathrm{h}}$ Contrast: $0.50\{(\mathrm{AH} 80 \mathrm{~s}+\mathrm{A} 80 \mathrm{~s})-($ AHref + Aref $)\}$.

${ }^{\mathrm{i}}$ Contrast: $0.50\{(\mathrm{HA} 80 \mathrm{~s}+\mathrm{H} 80 \mathrm{~s})-(\mathrm{AH} 80 \mathrm{~s}+\mathrm{A} 80 \mathrm{~s})\}$.

${ }^{\mathrm{j}}$ Contrast: $0.50\{($ HAref + Href $)-($ AHref + Aref $)\}$.

${ }^{\mathrm{k}}$ Contrast: crosses with Hereford dams vs. crosses with Angus dams.

${ }^{\mathrm{l}} \sigma_{\mathrm{p}}=$ phenotypic standard deviation, $\sigma_{\mathrm{g}}=$ genetic standard deviation, and $\sigma_{\mathrm{c}}=$ permanent environmental standard deviation, derived from variance component estimates; $\mathrm{h}^{2}=$ heritability.

pattern was found for Angus cows, but the difference was significant at $2 \mathrm{yr}$ of age ( 0.24 point) and highly significant at 5 and $6 \mathrm{yr}$ of age, when greater than 0.40 point. Response to selection for production traits has resulted in taller and heavier cows with greater output and greater nutritional requirements, which appear to have been associated with lower condition scores. On average, cows with 1980s Angus sires had approximately the same condition scores as cows with 1980s Hereford sires. The same was true for Hereford and Angus cows with reference sires. On average, cows with Angus dams had slightly greater condition scores than cows with Hereford dams with differences ( 0.1 to 0.2 point) that tended to increase with age and which were highly significant at all ages except at $3 \mathrm{yr}(P<0.05)$.

Gregory et al. $(1992,1995)$ reported condition scores of cows from 2 to $7+y r$ of age of purebred and composite breeds for the USMARC GPU Project. Estimates ranged from 6.0 to 7.0 and from 5.6 to 6.4 points for Hereford and Angus cows, respectively. Condition scores were slightly greater for Hereford cows than for Angus cows at all ages, but differences were no greater than 0.5 point. Spelbring et al. (1977) reported condition scores from a diallel experiment with Angus and Shorthorn in which Angus cows exceeded Shorthorn-Angus cows by 0.2 to 0.7 point ( 5 -to- 15 scale) at all ages ( 3 to $5 \mathrm{yr}$ ), similar to this study, in which differences were 0.4 to 0.6 point for cows with reference sires. Differences for the more recent sample of Angus sires were less in the present study (0.1 to 0.3 point). Nadarajah et al. (1984) reported scores of 2.9, 3.1, 3.5, 3.4, and 3.4 (1to-5 scale) points at $32,44,56,68$, and 84 mo of age, respectively, for Angus cows, which were slightly greater than the corresponding scores of Charolais-Angus cows $(2.7,3.2,2.9,3.1$, and 3.1 points) at each age, except at 44 mo of age. Marlowe and Morrow (1985) reported condition scores of 2.6, 2.6, 2.7, 2.8, 2.7, and 2.7 (1-to-5 scale) points for 2- to 7-yr-old Angus cows in Virginia, in a study that also reported weight adjusted for condition score. Condition scores of 5-yr-old Hereford cows in Montana and Florida were reported to be 6.7 and 6.1 (1-to-9 scale) points, respectively, in a study of location by origin interaction (Butts et al., 1971). Benyshek and Marlowe (1973) reported a mean 
score of 3.1 (1-to-5 scale) points in 7-yr-old Hereford cows.

Bowden (1980) evaluated condition with weight-toheight ratio and with ultrasound measurement of backfat thickness in crossbred cows with Angus dams at 2 yr of age. In that study, HA cows had the greatest fat thickness, followed closely by Charolais-Angus cows. In Scotland, Osoro and Wright (1992) reported that condition scores of Shorthorn-Galloway cows were significantly greater than scores for Hereford-Holstein cows (2.37 points on a 6 -point scale).

\section{Implications}

Estimates of breed-group differences for weight, height, and condition score of cows were significant $(P$ $<0.05$ ) between Hereford-Angus reciprocal crosses and topcrosses with Charolais, Shorthorn, Salers, Nellore, Galloway, Piedmontese, and Longhorn sires. Such differences can be used to match breed resources with production systems and market requirements to optimize beef production. Cows with Angus and Hereford sires from different samples (bulls born from 1962 through 1970 vs. bulls born from 1980 through 1987) differed importantly for all traits. This result indicates that care should be taken to account for time trends within breeds for traits and breeds being considered in crossbreeding or purebreeding management systems.

\section{Literature Cited}

Arango, J. A., L. V. Cundiff, and L. D. Van Vleck. 2002a. Genetic parameters for weight, weight adjusted for body condition score, height, and body condition score in beef cows. J. Anim. Sci. 80:3112-3122.

Arango, J. A., L. V. Cundiff, and L. D. Van Vleck. 2002b. Breed comparisons of Angus, Charolais, Hereford, Jersey, Limousin, Simmental, and South Devon for weight, weight adjusted for body condition score, height and body condition score of cows. J. Anim. Sci. 80:3123-3132.

Arango, J. A., L. V. Cundiff, and L. D. Van Vleck. 2002c. Comparisons of Angus-, Braunvieh-, Chianina-, Hereford, Gelbvieh-, Maine Anjou-, and Red Poll-sired cows for weight, weight adjusted for body condition score, height and body condition score. J. Anim. Sci. 80:3133-3141.

Arango, J. A., L. V. Cundiff, and L. D. Van Vleck. 2002d. Breed comparisons of Angus, Braham, Hereford, Pinzgauer, Sahiwal, and Tarentaise for weight, weight adjusted for condition score, height, and body condition score. J. Anim. Sci. 80:3142-3149.

Benyshek, L. L., and T. J. Marlowe. 1973. Estimating heritability of Hereford cow weights. J. Anim. Sci. 36:854-861.

Boldman, K. G., L. A. Kriese, L. D. Van Vleck, C. P. Van Tassell, and S. D. Kachman. 1995. A manual for use of MTDFREML. A set of programs to obtain estimates of variances and covariances [Draft]. USDA, Agricultural Research Service, Clay Center, NE.

Bowden, D. M. 1980. Feed utilization for calf production in the first lactation by 2 yr-old F1 crossbred cows. J. Anim. Sci. 51:304-315.
Brown, C. J., and L. Franks. 1964. Factors affecting size of young beef cows. J. Anim. Sci. 23:665-668.

Brown, C. J., M. L. Ray, W. Gifford, and R. S. Honea. 1956. Growth and development of Aberdeen-Angus cattle. Ark. Agr. Exp. Sta. Bull. 571.

Butts, W. T., M. Koger, O. F. Panish, W. C. Burns, and E. J. Warwick. 1971. Performance of two lines of Hereford cattle in two environments. J. Anim. Sci. 33:923-932.

Cundiff, L. V., K. E. Gregory, R. M. Koch, and G. E. Dickerson. 1986. Genetic diversity among cattle breeds and its use to increase beef production in a temperate environment. Pages 271-282 in Proc. 3rd World Cong. Genet. Appl. Livest. Prod., Lincoln, NE.

Cundiff, L. V., K. E. Gregory, and R. M. Koch. 1998. Germplasm evaluation in beef cattle-Cycle IV: Birth and weaning traits. J. Anim. Sci. 76:2528-2535.

Dickerson, G. E. 1978. Animal size and efficiency: Basic concepts. Anim. Prod. 27:367-379.

Frahm, R. R., and D. M. Marshall. 1985. Comparisons among twobreed cross cow groups. I. Cow productivity and calf performance to weaning. J. Anim. Sci. 61:844-855.

Gregory, K. E., L. V. Cundiff, and R. M. Koch. 1992. Breed effects and heterosis in advanced generations of composite populations on actual weight, adjusted weight, hip height, and condition score of beef cows. J. Anim. Sci. 70:1742-1754.

Gregory, K. E., L. V. Cundiff, and R. M. Koch. 1995. Genetic and phenotypic (co)variances for production traits of female populations of purebred and composite beef cattle. J. Anim. Sci. 73:2235-2242.

Jeffery, H. B., and R. T. Berg. 1972. An evaluation of several measurements of beef cow size as related to progeny performance. Can. J. Anim. Sci. 52:23-37.

Koger, M. 1980. Effective crossbreeding systems utilizing Zebu cattle. J. Anim. Sci. 50:1215-1220.

Marlowe, T. J., and G. A. Morrow. 1985. Heritabilities and phenotypic, genetic and environmental correlations for weight, grade and condition of Angus cows. J. Anim. Sci. 60:82-88.

Meyer, K. 1995. Estimates of genetic parameters for mature weight of Australian beef cows and its relationship to early growth and skeletal measures. Livest. Prod. Sci. 44:125-137.

Montaño-Bermudez, M. 1987. Components of performance and biological efficiency of crossbred beef cattle with different genetic potential for milk. Ph.D. Diss. Univ. of Nebraska, Lincoln.

Nadarajah, K., T. J. Marlowe, and D. R. Notter. 1984. Growth patterns of Angus, Charolais, Charolais $\times$ Angus and Holstein $\times$ Charolais cows from birth to maturity. J. Anim. Sci. 59:957-966.

Osoro, K., and I. A. Wright. 1992. The effect of body condition, live weight, breed, age, calf performance, and calving date on reproductive performance of spring-calving beef cows. J. Anim. Sci. 70:1661-1666.

Sacco, R. E., J. F. Baker, T. C. Cartwright, C. R. Long, and J. O. Sanders. 1990. Measurements at calving for straightbred and crossbred cows of diverse types. J. Anim. Sci. 68:3103-3108.

Smith, G. M., H. A. Fitzhugh Jr., L. V. Cundiff, T. C. Cartwright, and K. E. Gregory. 1976. Heterosis for maturing weight patterns in Hereford, Angus and Shorthorn cattle. J. Anim. Sci. 43:380-388.

Spelbring, M.C., T. G. Martin, and K. J. Drewry. 1977. Maternal productivity of crossbred Angus $\times$ Milking Shorthorn cows. I. Cow and calf weights and scores. J. Anim. Sci. 45:969-975.

Thallman, R. M., L. V. Cundiff, K. E. Gregory, and R. M. Koch. 1999. Germplasm evaluation in beef cattle-Cycle IV: postweaning growth and puberty of heifers. J. Anim. Sci. 77:2651-2659. 